\title{
10
}

\section{Traditional marine resources and their use in contemporary Hawai ${ }^{\prime} i^{1}$}

\author{
Alan M. Friedlander, Janna M. Shackeroff \\ and John N. Kittinger
}

\section{Introduction}

Marine resources were important to the ancient Hawai'ians for subsistence, culture and survival. But in recent times, intensive fishing pressure, particularly in more populated areas, has led to substantial declines in many highly prized and vulnerable species. ${ }^{2}$ Factors contributing to this include a growing human population, destruction of habitat, introduction of new and overly efficient fishing techniques (e.g. inexpensive monofilament gill nets, SCUBA,

1 This chapter is adapted from Friedlander, A.M., Shackeroff, J.M. \& Kittinger, J.N., 2013. 'Customary marine resource knowledge and use in contemporary Hawai'i'. Pacific Science 67(3): 441-60.

2 Friedlander, A.M. \& De Martini, E.E., 2002. 'Contrasts in density, size, and biomass of reef fishes between the northwestern and the main Hawai'ian Islands: the effects of fishing down apex predators'. Marine Ecology Progress Series 230: 253-64; Williams, I.D., Walsh, W.J., Schroeder, R.E., Friedlander, A.M., Richards, B.L. \& Stamoulis, K.A., 2008. 'Assessing the relative importance of fishing impacts on Hawai'ian coral reef fish assemblages along regionalscale human population gradients'. Environmental Conservation 35: 261-72. 
Global Positioning System or GPS), and loss of traditional conservation practices. ${ }^{3}$ Further, there is poor compliance with state fishing laws and regulations and insufficient enforcement.

Owing to the failures of conventional marine management, government and local communities are increasingly interested in conserving marine ecosystems for future generations. Efforts underway throughout Hawai'i to better understand, manage and conserve ocean resources include a shift towards ecosystem-based management by government agencies, development of school curricula and university programs in natural resource management, and the inclusion of stakeholders in the management process. Integrating Native Hawai'ian traditional ecological knowledge (TEK) ${ }^{4}$ and traditional practices into contemporary marine management is an important element in these approaches, and a number of communities around the state are implementing these strategies (Figure 22). These efforts face challenges deriving from such things as power and politics, ${ }^{5}$ postcolonial legacies, ${ }^{6}$ and epistemological differences. ${ }^{7}$ How TEK is integrated into contemporary Hawai'ian marine resource management and the impact this has on ocean condition may provide insights into better management practices elsewhere and is the focus of this chapter.

3 Friedlander, A.M., Brown, E.K., Jokiel, P.L., Smith, W.R. \& Rodgers, K.S., 2003. 'Effects of habitat, wave exposure, and marine protected area status on coral reef fish assemblages in the Hawai'ian archipelago'. Coral Reefs 22: 291-305.

4 Berkes, F., Colding, J. \& Folke, C., 2000. 'Rediscovery of traditional ecological knowledge as adaptive management'. Ecological Applications vol. 10:1251-62.

5 Shackeroff, J.M. \& Campbell, L.M., 2007. 'Traditional ecological knowledge in

conservation research: problems and prospects for their constructive engagement'. Conservation \& Society 5: 343-60.

6 Tuhiwai-Smith, L., 1999. Decolonizing Methodologies: Research and Indigenous Peoples. New York: Zed Books Ltd.

7 Agrawal, A., 2002. 'Indigenous knowledge and the politics of classification'. International Social Science Journal 54: 287-97. 


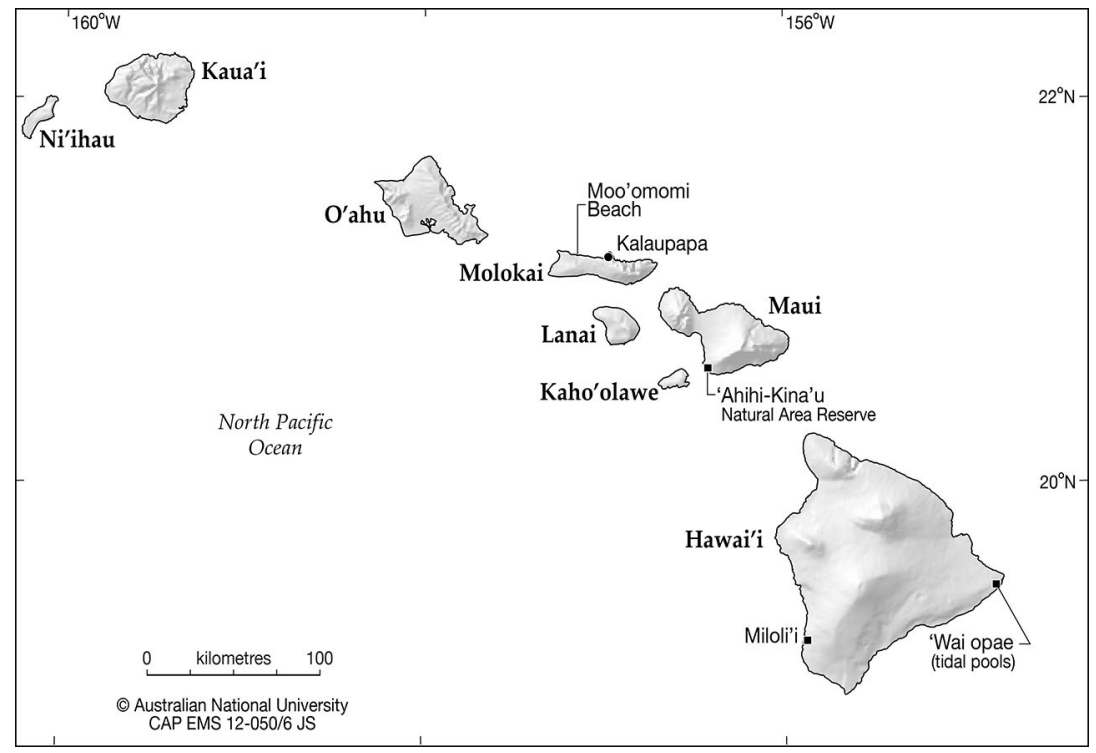

Figure 22: Map of Hawai'i

Source: (C) The Australian National University CAP EMS 12-050/6 JS

\section{Marine resource use, knowledge and management in ancient Hawai' $i$}

Hawai'ians of old (pre-1800) depended on fishing for survival, which motivated them to acquire a sophisticated understanding of the factors that caused limitations and fluctuations in their marine resources. Based on their familiarity with specific places and through much trial and error, Hawai'ian communities were able to develop social and cultural controls on fishing that fostered sustainable use of marine resources. ${ }^{8}$ In traditional Hawai'ian society, the basic unit of land division and socioeconomic organisation was the ahupua' $a$, which radiated from interior uplands through valleys into the sea and was managed adaptively according to resource availability and fluctuations. ${ }^{9}$ This type of land division allowed integrated

8 Titcomb, M., 1972. Native Use of Fish in Hawai' $i$. Honolulu: University of Hawai'i Press.

9 Kirch, P.V., 1989. The Evolution of the Polynesian Chiefdom. Cambridge University Press. 
management of society and natural resources - forests, agricultural land, shoreline and ocean — by a single sociopolitical group at the local scale.

Within ahupua'a, fishing activities and catch distribution were strictly disciplined by kapu (rules). Harvest management was not based on a specific amount of fish but on identifying the specific times and places that fishing could occur so as to not disrupt basic processes and habitats of important food resources. ${ }^{10}$ By allowing fish populations to replenish themselves, and by not interfering with important activities such as spawning, traditional Hawai'ian communities were able to maintain the productivity and fisheries yield near their villages.

Konohiki, land agents within ahupua'a, enforced kapu on behalf of ali' $i$ (chiefs). Knowledgeable of the lunar and seasonal cycles that cause resources to fluctuate, konohiki were often advised by kupuna (elders) and po'o lawai'a (master fishermen). Master fishermen played a prominent role in the culture, were of a special lineage, and trained for years as apprentices. Their awareness of subtle changes in the environment made them sentinels of the ecosystem. ${ }^{11}$

Fishing activities and catch distribution were strictly disciplined by rules for which death was prescribed for severe transgressions. ${ }^{12}$ Taking only so much so as not to diminish the supply, and not disrupting spawning cycles, represented some of the foundational rules. The first fish of the catch were reserved for kupuna and offerings to ancestors. $K o^{\prime} a$, or special aggregation sites, were tended and fished with care to prevent depletion. Certain species such as moi (Pacific threadfin) were reserved only for the chiefs. Other food such as ulua (jacks), kumu (an endemic goatfish) and honu (turtles) were the embodiment of the gods and were restricted for consumption by women. Many of these laws provided protection for important species and allowed Hawai'ians to derive sustenance from the ocean for millennia.

10 Friedlander, A., Poepoe, K., Poepoe, K., Helm, K., Bartram, P., Maragos, J. \& Abbott, I., 2002. 'Application of Hawai'ian traditions to community-based fishery management'. Proc. 9th Inter. Coral Reef Symp vol. 2: 813-18; Poepoe, K., Bartram, P. \& Friedlander, A., 2007. 'The use of traditional Hawai'ian knowledge in the contemporary management of marine resources'. In N. Haggan, B. Neis \& I. Baird (eds), Fishers' Knowledge in Fisheries Science and Management. Paris: UNESCO, pp. 117-41.

11 Poepoe et al., 2007.

12 Titcomb, 1972. 


\section{Demise of the traditional system}

Following Western contact, a variety of sociopolitical factors led to the demise of the traditional system of marine resource management in the late eighteenth to early nineteenth centuries. The Native Hawai'ian population declined precipitously due to introduced diseases, leading to widespread loss of knowledge and decline in the transmission of TEK. Western influences resulted in intensive resource extraction that was directed towards the acquisition of foreign goods and the beginnings of a cash economy. In 1848, the Mahele 'Aina (Land Division Act) established fee simple ownership of land, enabling foreigners to purchase land, which ushered in the plantation era and resulted in an influx of different ethnic groups. ${ }^{13}$ While this led to the breakdown of the ahupua'a system, laws granting management of the near-shore fisheries resources by the konohiki remained. Annexation by the United States, however, and the Organic Act of 1900 that followed, repealed all konohiki rights and opened fishing to all citizens. ${ }^{14}$

The early 1900s saw the solidification of the cash economy and large increases in the commercial landing of marine resources. Japanese immigrants introduced new fishing technologies and replaced Native Hawai'ian people as the dominant commercial fishermen. ${ }^{15}$ Just prior to the Second World War, commercial fishing in Hawai'i was a multimillion dollar industry that employed hundreds of people directly and thousands indirectly. But, after the war, many fishermen were unwilling or unable to return to commercial fishing. Recent decades have seen Hawai'i's rapid growth in tourism, an increasingly urban resident population, and the continued development of shoreline areas for tourism and recreation. The character of coastal fisheries is dominated by recreational anglers and a greater number of part-time commercial fishers who have curtailed their fishing to take advantage of more lucrative economic activities.

13 Chinen, J.J., 1958. The Great Mahele: Hawai'i's Land Division of 1848. Honolulu: University of Hawai'i Press.

14 Meller, N., 1985. Indigenous Ocean Rights in Hawai'i. Sea Grant Marine Policy and Law Report UNIHI-SEAGRANT-MP-86-01. Honolulu: UH Sea Grant College Program.

15 Schug, D., 2001. 'Hawai'i's commercial fishing industry: 1820-1945'. Hawai'ian J. History 35: $15-34$. 


\section{Contemporary centralised management}

Today, myriad state and federal authorities provide for the management of Hawai'i's coastal resources and do so based on Western science and implemented by government resource managers. As compared to traditional forms, contemporary fisheries management strategies are based on principles of maximum sustainable yield and conserving species at current levels. Knowledge is accrued through quantitative studies of single stocks with people considered separate from the natural world, and information transmitted in published literature. These, in addition to the scale, methods of assessment, fishing controls and planning horizons differ greatly from traditional Hawai'ian strategies of resource management.

Table 1. Comparisons of customary and conventional marine resource management in Hawai' $i$ and application in integrated approaches.

\begin{tabular}{|l|l|l|l|}
\hline $\begin{array}{l}\text { Customary } \\
\text { management }\end{array}$ & Description & $\begin{array}{l}\text { Conventional } \\
\text { management }\end{array}$ & Integrated approaches \\
\hline Spatial & $\begin{array}{l}\text { Areas closed to } \\
\text { fishing (kapu zones), } \\
\text { can be temporary or } \\
\text { permanent (e.g. during } \\
\text { Makahiki; rotating } \\
\text { Aku/'Ōpelu kapu) }\end{array}$ & $\begin{array}{l}\text { Marine } \\
\text { protected areas, } \\
\text { temporary } \\
\text { fisheries } \\
\text { closures }\end{array}$ & $\begin{array}{l}\text { Community managed } \\
\text { marine areas, with } \\
\text { established kapu zones } \\
\text { to replenish resources if } \\
\text { needed }\end{array}$ \\
\hline Temporal & $\begin{array}{l}\text { Restricting fishing/ } \\
\text { harvesting activities } \\
\text { during specific times. } \\
\text { Often short duration, } \\
\text { specific to certain } \\
\text { species, and for } \\
\text { specific events (e.g. } \\
\text { religious ceremonies, } \\
\text { protect spawning } \\
\text { aggregations) }\end{array}$ & Closed seasons & $\begin{array}{l}\text { Community-based moon } \\
\text { calendars showing which } \\
\text { species are spawning and } \\
\text { should be kapu }\end{array}$ \\
\hline & $\begin{array}{l}\text { Restrictions on certain } \\
\text { harvesting methods } \\
\text { or techniques; chiefly } \\
\text { control of materials for } \\
\text { fishing gear and boats, } \\
\text { which limited access } \\
\text { to some fisheries } \\
\text { resources }\end{array}$ & $\begin{array}{ll}\text { Gear } \\
\text { prohibitions }\end{array}$ & $\begin{array}{l}\text { Restrictions on certain } \\
\text { gear (e.g. for laynets, or no } \\
\text { spearfishing with SCUBA) }\end{array}$ \\
\hline Gear & & \\
\hline
\end{tabular}




\begin{tabular}{|c|c|c|c|}
\hline $\begin{array}{l}\text { Customary } \\
\text { management }\end{array}$ & Description & $\begin{array}{l}\text { Conventional } \\
\text { management }\end{array}$ & Integrated approaches \\
\hline Effort & $\begin{array}{l}\text { Limits on access to } \\
\text { certain areas (e.g. only } \\
\text { residents of ahupua'a } \\
\text { could access adjacent } \\
\text { reef); limiting who can } \\
\text { harvest certain species, } \\
\text { use certain gear, or fish } \\
\text { certain areas }\end{array}$ & $\begin{array}{l}\text { Permitting } \\
\text { territorial user } \\
\text { rights systems } \\
\text { for fisheries } \\
\text { (TURFS) and } \\
\text { limited entry } \\
\text { fisheries }\end{array}$ & $\begin{array}{l}\text { Community-based } \\
\text { subsistence fishing areas } \\
\text { with rules developed } \\
\text { in an inclusive, place- } \\
\text { based manner; permitted } \\
\text { access for local families or } \\
\text { residents in a district (moku) }\end{array}$ \\
\hline Species & $\begin{array}{l}\text { Prohibitions on } \\
\text { consumption of certain } \\
\text { species, often related } \\
\text { to class, gender, or } \\
\text { lineage }\end{array}$ & $\begin{array}{l}\text { Protection of } \\
\text { vulnerable or } \\
\text { endangered } \\
\text { species }\end{array}$ & $\begin{array}{l}\text { Bans on certain species } \\
\text { until populations } \\
\text { regenerate; limits on harvest } \\
\text { for culturally significant } \\
\text { species or resources that } \\
\text { contribute significantly to } \\
\text { local food security }\end{array}$ \\
\hline Catch & $\begin{array}{l}\text { Restricting the quantity } \\
\text { of harvest; social } \\
\text { norms discourage } \\
\text { wasting and other } \\
\text { harmful practices }\end{array}$ & $\begin{array}{l}\text { Total allowable } \\
\text { catch; } \\
\text { individually } \\
\text { transferable } \\
\text { quotas (ITQs) }\end{array}$ & $\begin{array}{l}\text { Communal harvest events } \\
\text { to sustain connections to } \\
\text { local resources; educational } \\
\text { and outreach programs } \\
\text { to connect community } \\
\text { members and build social } \\
\text { capital }\end{array}$ \\
\hline Aquaculture & $\begin{array}{l}\text { Creation of fishponds, } \\
\text { stocked with wild- } \\
\text { caught juveniles, } \\
\text { which sequestered } \\
\text { nutrients from } \\
\text { uplands and served } \\
\text { as insurance against } \\
\text { famine }\end{array}$ & $\begin{array}{l}\text { Modern } \\
\text { aquaculture }\end{array}$ & $\begin{array}{l}\text { Rebuild and revitalise } \\
\text { fishponds to provide } \\
\text { fisheries resources to } \\
\text { communities; explore } \\
\text { creation of Community } \\
\text { Supported Fisheries } \\
\text { (CSF) models to connect } \\
\text { communities to local } \\
\text { fishponds }\end{array}$ \\
\hline Enforcement & $\begin{array}{l}\text { Violations of } \\
\text { customary restrictions } \\
\text { resulted in sanctions } \\
\text { or punishments that } \\
\text { could be severe }\end{array}$ & $\begin{array}{l}\text { Fines; penalties; } \\
\text { licence } \\
\text { revocation }\end{array}$ & $\begin{array}{l}\text { Develop and implement } \\
\text { a penalty schedule of } \\
\text { graduated sanctions that } \\
\text { includes community service } \\
\text { by violators in restoration } \\
\text { activities }\end{array}$ \\
\hline
\end{tabular}

Source: Adapted from Cinner and Aswani (2007), McClenachan and Kittinger (2012), and Jokiel et al. (2011).

Hawai'i's contemporary coastal resource management reflects the historically sectoral-based governance of oceans in the United States, where at least 20 federal agencies implement over 140 oceanrelated statutes. ${ }^{16}$ It is well documented that contemporary marine

16 Crowder, L.B. et al. 2006. 'Resolving mismatches in U.S. ocean governance'. Science 313: 617-18. 
management is riddled with gaps and overlaps. ${ }^{17}$ Centralised, top down and sectoral twentieth-century marine management tends to address single species or single issues rather than the system holistically. ${ }^{18}$ In Hawai'i's geography, centralisation means that most marine management is enacted in urban Honolulu, far removed from the local communities of the neighbouring islands.

Contemporary marine management in Hawai'i is complicated by additional problems. The heterogeneity of Hawai'i's marine resources, biogeography and the local communities is not well suited to centralised, top-down management. Issues surrounding political appointments, failed management strategies like rotational closures, ${ }^{19}$ and some of the United States' lowest levels of resource management funding contribute to the failure of contemporary management.

\section{Renaissance of traditional management in the Pacific}

The renaissance of traditional management throughout the Pacific and rediscovery of traditional techniques has led to improved management of fisheries in the region. ${ }^{20}$ Governments of many Pacific Islands are recognising customary marine tenure (CMT) rights by communities and are helping to facilitate more localised management of marine resources. In Fiji, a national network of non-governmental and government organisations supports over 200 locally managed marine areas that are leading to the revival of traditional resource practices to improve management and maximise benefits to local communities. ${ }^{21}$

17 Young, O. R. 2002. Institutional Dimensions of Environmental Change: Fit, Interplay, and Scale. Cambridge, Mass.: MIT Press.

18 Leslie, H. \& McLeod, K., 2007. 'Confronting the challenges of implementing marine ecosystem-based management'. Front Ecol Environ 5: 540-48.

19 Williams, I.D., Walsh, W.J., Miyasaka, A. \& Friedlander. A.M. 2006. 'Effects of rotational closure on coral reef fishes in the Waikiki-Diamond Head Fishery Management Area, Oahu, Hawai'i'. Marine Ecology Progress Series 310: 139-49.

20 Johannes, R.E., 2002. 'The renaissance of community-based marine resource management in Oceania'. Annual Review of Ecology and Systematics 33: 317-40.

21 Veitiyaki, J., Aalbersberg, B., Tawake, A., Rupeni, E. \& Tabunakawai, K., 2003. 'Mainstreaming resource conservation: the Fiji Locally Managed Marine Area Network and its influence on national policy'. Resource Management in Asia-Pacific. Working Paper no. 42. Canberra: Resource Management in Asia-Pacific Program, Research School of Pacific and Asian Studies, The Australian National University. 
Palau's traditional practice of bul involves the council of chiefs placing reef areas off limits to fishing during known spawning and feeding periods. ${ }^{22}$ This traditional bul system has become the basis for Palau's network of protected areas and its protected area network law. These successes are not restricted to the Pacific Islands and, indeed, are found in many other regions around the world. ${ }^{23}$

\section{Reviving traditional practices in Hawai' $i$}

Reviving traditional practices and integrating them into contemporary activities is gaining momentum in Hawai'i. Despite the decline in traditional marine resource management since Western contact, there remain pockets of cultural continuity in Hawai'i where TEK and practice have persisted unbroken for millennia. ${ }^{24}$ 'Cultural kipuka' represent areas of (usually rural) Hawai'i where cultural practice remains unbroken and authentic. ${ }^{25}$ In these places, where TEK is intact and transmission of knowledge continues, kupuna and knowledgeable practitioners can be engaged as holders of expert knowledge. The continuance of subsistence fishing activities is one of the ways that knowledge, values and identity are transferred to succeeding generations. Cultural survival is thus entwined with resource conservation.

TEK is gaining attention in Hawai' $\mathrm{i}$, as elsewhere, because ocean ecosystem structure and function continue to decline, despite conventional marine managements efforts. Persistent ecological decline, threats to the transmission of TEK, as well as the increase in power and political voice of Native Hawai'ian people represent potential reasons for the increasing attention to TEK. Hawai'ian scholars have recorded

22 Johannes, R.E., 1981. Words of the Lagoon: Fishing and Marine Lore in the Palau District of Micronesia. Berkeley: University of California Press.

23 Berkes et al., 2000; Cinner, J.E., Wamukota, A., Randriamahazo, H. \& Rabearisoa, A., 2009. 'Toward institutions for community-based management of inshore marine resources in the western Indian ocean'. Marine Policy 33(3): 489-96.

24 McGregor, D., 2007. Na Kua'aina: Living Hawai'ian Culture. Honolulu: Bishop Museum Press.

25 McGregor, 2007. 
TEK with attention to environmental change and practices, ${ }^{26}$ and cross-cultural and interdisciplinary teams are beginning to elicit TEK to integrate traditional and Western scientific perspectives. ${ }^{27}$

Community involvement in marine resource management has increased markedly in the past few years. The following pages summarise the efforts across the state and case studies of local communities that are engaged in TEK.

\section{Regulation and policy integrating TEK}

Hawai'ian TEK is being enveloped into governance of marine resources, from the local community to the federal scale. For example, the Western Pacific Regional Fishery Management Council is now required by federal law to integrate Native Hawai'ian traditional knowledge into fisheries management plans, and the council is also incorporating the ahupua' $a$ concept into management. In addition, the authorising regulations of Papahānaumokuākea Marine National Monument (PMNM), which manages the Northwestern Hawai'ian Islands, are based on pono (righteousness) practices, or a sense of Native Hawai'ian cultural integrity. PMNM's Monument Management Plan (2008) calls for the incorporation of TEK into day-to-day management.

At the state level, the Hawai'i Ocean Resources Management Plan has moved to a place-based approach, emphasising integration from mountain to sea. Traditional management is explicit in strategic actions, such as developing integrated natural and cultural resource planning and through demonstration ahupua'a projects. Additionally, it aims to establish island-wide support networks to increase community dialogue, develop a framework for education and build partnerships among various stakeholders. ${ }^{28}$

\footnotetext{
26 For example, Kamakau, S.M., 1976. The Works of the People of Old (Na hana a ka po'e kahiko). Translated from the newspaper Ke Au 'Oko'a by M.K. Pukui. Honolulu: Bishop Museum Press; Maly, K., \& Pomroy-Maly, O., 2003. Ka Hana Lawai'a a me na Ko'a o na Kai'Ewalu. A History of Fishing Practices and Marine Fisheries of the Hawai'ian Islands. Honolulu: The Nature Conservancy.

27 For example, Poepoe et al., 2007.

28 Hawai'i Ocean Resources Management Plan (ORMP). 2008. Final Report to the TwentyFourth Legislature, Regular Session of 2007 Coastal Zone Management Program. Office of Planning, DBEDT.
} 


\section{Knowledge-sharing and capacity-building}

A variety of community-based initiatives have emerged to ensure multigenerational knowledge-sharing and to build capacity across the state to protect and perpetuate traditional knowledge. Non-profit organisations, state and federal agencies, and communities are working in concert towards these ends. The Managing Better Together Learning Network, a project that brought together community marine practitioners to work toward improving their practice through sharing lessons and strategies exemplifies knowledge-sharing and capacitybuilding efforts that are bubbling up from Hawai'ian communities. ${ }^{29}$ Since 2003, the network has grown from 12 to 22 participating communities and it is fostered by community-based organisations such as the Community Conservation Network and Hawai'i Community Stewardship Network. ${ }^{30}$

\section{Enforcement}

Much lore and intrigue surrounds the traditional Hawai'ian system of kapu, known for harsh enforcement of punishments for fishing infractions, sometimes with death. Traditionally, enforcement was enacted at the local level by konohiki acting upon real-time observations such as seasonality and population status. Contemporary communities in Hawai'i commonly complain about the lack of enforcement of marine regulations. As a result, community-based enforcement programs were initiated across Hawai'i, with Maui's 'Ahihi-Kina'u Natural Area Reserve in 1997 and, in 2003, with the Reef Stewardship Program at Wai 'Opae and Coast Watch at Miloli'i. These efforts gelled into 'Makai Watch', a formal partnership between the state and non-profit organisations that focuses on caring for near-shore marine resources with the active participation of local communities. Modelled after the Neighbourhood Watch program, Makai Watch volunteers in over 10 communities statewide serve as the 'eyes and ears' for conservation

29 Hawai'i Community Foundation, 2009. hawaiicommunityfoundation.org/index.php?id=257, Accessed 4 September 2009.

30 Hawai'i Community Foundation, 2009. 
and resource enforcement officials. While not specifically a program integrating TEK, it represents a return to local enforcement and draws institutional parallels to traditional Hawai'i.

\section{Examples of the contemporary use of traditional knowledge}

\section{Mo‘omomi Bay, Moloka‘i}

The community in the Ho'olehu Hawai'ian Homesteads on the island of Moloka' $i$ is actively engaged in managing their resources as well as educating users about traditional methods. Subsistence activities, including farming and fishing, supply about one-third of the food needed by the approximately 1,000 Hawai'ian residents of this community. The 1994 Hawai'i State Legislature created a process for designating community-based subsistence fishing areas. In response to this legislation, the local community created an organisation (Hui Malama o Mo'omomi), and prepared a fisheries management plan for the north-west coast of Moloka'i. ${ }^{31}$

Community resource monitors place an emphasis on high resolution monitoring using traditional observation methods that provide the basis for understanding local fisheries dynamics and adjusting fishing effort so that resources are not harvested at the wrong times and places. ${ }^{32}$ By identifying peak spawning periods for important resource species, closures can be applied so as not to disturb the natural rhythms of these species. By observing spawning behaviour and gonad development, community monitors were able to develop a calendar identifying the spawning periods for the major resource species that can be used to validate the establishment of seasonal kapu to protect spawners.

An example of this strategy is the life cycle model developed for moi, an important resource both in ancient times and today. Ancient Hawai'ians had names for each life phase of the moi, and recognised

31 Hui Malama o Mo'omomi, 1995. Proposal to Designate Mo'omomi Community-Based Subsistence Fishing Area, Northwest Coast of Moloka'i. Prep. for Dept. of Land and Natural Resources, State of Hawai'i.

32 Friedlander et al., 2002. 
that it changed sex. Traditional Hawai'ian conservation principles for moi included restrictions on the harvest of large females, depending on population structure, and restrictions on harvest during the spawning season. Minimising disturbance to spawning and nursery habitats was another important conservation practice.

Community-sanctioned norms for fishing conduct are reinforced through continual feedback based on site resource monitoring, education and peer pressure. The most effective means of eliciting proper conduct of fishing is through education of young people in the community to understand that they have responsibilities, as well as rights, for marine resource use. The continuation of traditional Hawai'ian practices in and around Mo'omomi Bay helps to maintain social and cultural identity and reinforces the values shared by the Ho'olehua community.

\section{Kaho'olawe}

For 50 years this island functioned as a de facto natural reserve since it served as a military bombing range until 1990. In 2003 access to Kaho'olawe was returned the state of Hawai' $i$ and the Kaho'olawe Island Reserve Commission (KIRC) was established to manage the island and the surrounding waters in trust for the general public and the future Native Hawai'ian sovereign entity. This commission fosters access for Native Hawai'ians to practice cultural, spiritual and subsistence activities on the island and in the adjacent marine waters. The ocean management plan outlines fishing areas, cultural and subsistence activities, and enforcement policies that aim to integrate traditional practices with contemporary management.

Limited trolling is allowed in the reserve waters on two weekends each month. Vessel owners must register their vessel with the KIRC, apply for a permit and file catch reports. Applicants seeking to exercise traditional and customary rights and practices within the reserve must have their requests approved by the commission after review and consultation with cultural practitioners. Enforcement is conducted by state and federal agencies with additional surveillance provided by cultural practitioners. The KIRC mission also monitors the status of the ocean resources surrounding Kaho'olawe and improving the health of offshore areas. 


\section{Miloli'i, Hawai'i}

The predominantly Native Hawai'ian village of Miloli'i in 2005 secured State Act 232, establishing a community-based subsistence fishing area and thereby allowing the community to regulate its local coastal waters based on Native Hawai'ian principles. Act 232 directed the Hawai'i Department of Land and Natural Resources to develop proposed rules to ensure sustainable stocks of fish to preserve the traditional Hawai'ian lifestyle of the Miloli'i community. The Miloli'i community was once famous for the fishing of 'opelu (mackerel scad). While 'opelu is still fished by a few community members, traditional technology and practices have not been in regular use for over 50 years.

Numerous traditional practices associated with 'opelu fishing helped to maintain healthy stocks. These included using only vegetable matter as chum, because fish-matter chum causes more rapid decomposition of dried fish and attracts predators that disrupted the spawning aggregations. Additional practices were returning a minimum of two reproductive fish to the water with each net haul, using nets that were not capable of removing entire aggregations, restricting fishing during spawning periods and strictly enforcing seasonal closures. Other aspects of traditional fishing for 'opelu included an intimate knowledge of the aggregation sites $\left(k o^{\prime} a\right)$ and regular feeding of these $k o^{\prime} a$ prior to fishing. Ko' $a$ would be tended at least three days per week by feeding vegetable matter to the aggregating fish. Certain $k o^{\prime} a$ were tended and subsequently fished by certain families. Tending would continue for approximately two months prior to fishing season. The fishing season would close during the seasonally rough winter months.

Today, some members of the Miloli'i community have started to fish 'opelu again in the traditional way as part of an effort to teach youth about traditional practices and instill a sense of responsibility towards resource stewardship for many near-shore fisheries. One immediate manifestation of this effort is that, for the first time in over 60 years, a traditional 'opelu canoe is now being used to fish in ways that once sustained both people and the fish stocks upon which they depended. Additional activities that accompany these efforts include teaching youth and other community members how to monitor biological resources in their areas, collecting historical knowledge from kupuna about changes in the area's marine resources and teaching youth how to collect, document and present marine resource knowledge through 
film, as well as being founding forces in the Makai Watch program. Key community members believe that the sharing of traditional knowledge and values with youth will help build a solid foundation for future wise choices in resource management. ${ }^{33}$

\section{Kalaupapa, Moloka'i}

The remote Kalaupapa Peninsula on the island of Moloka'i achieved notoriety in 1865 when the Kingdom of Hawai'i instituted a centurylong policy of forced segregation of persons afflicted with Hansen's disease, ${ }^{34}$ also known as leprosy. Former Hansen's disease patients, despite being free to leave, still live at Kalaupapa. Public access to this community is limited because of regulations safeguarding privacy.

Owing to its isolation and unique political structure, Kalaupapa has a semblance of local management and control of its resources. Residents abide by state regulations but visitors are restricted to pole fishing only. Violations of the Kalaupapa fishing policy or state regulations result in the visitor being declared unwelcome and banned from future visits to Kalaupapa. Boats can come within one mile of the shoreline but the community often expresses their displeasure with these actions.

\section{Ni'ihau}

$\mathrm{Ni}$ 'ihau, the smallest inhabited island in Hawai'i, is privately owned with a resident population of about 130 Native Hawai'ians. The only Hawai'ian island where the Hawai'ian language is the primary spoken language, $\mathrm{Ni}^{\prime}$ ihau has no stores and inhabitants fish and farm for subsistence. The Ni'ihauan's believe that the commodification of marine resources elsewhere in Hawai'i has led to serious declines in marine resources, and therefore they allow no commercial harvest by residents. Fishing is limited to castnets, spears and pole and line. Other conservation strategies include taking only what is needed, rotating fishing areas and fishing a variety of species so as not to deplete certain locations or stocks. Boats from Kauai often come to $\mathrm{Ni}$ 'ihau but many residents have family on Kauai and intensive fishing by these outsiders is discouraged.

33 Walter Paulo, pers. comm. with the author.

34 www.nps.gov/kala/historyculture/hansensl.htm. 
These case studies illustrate both the parallels in renewed traditional resource management, as well as their heterogeneity. In such cases, one of the more common tools used to help regulate fishing effort and timing is the moon calendar. Hawai'ians of old developed this tool for holistic understanding of marine and terrestrial environments, ${ }^{35}$ and it is used today in select communities. ${ }^{36}$ The moon calendar emphasises certain repetitive biological and ecological processes (e.g. fish spawning, aggregation and feeding habits) that function at different time scales (e.g. seasonal, monthly and daily). Fishermen can use moon calendars by validating it at specific locations and regulating effort accordingly.

\section{Comparisons with other management strategies}

Scientific surveys of various locations around Hawai'i show that locations under community-based management with customary stewardship harbour fish biomass that is equal to or greater than no-take marine protected areas. Both of these types of management have significantly greater biomass compared with partially protected areas and areas that are open to all fishing. From this analysis, it is clear that community-managed areas, where appropriate, are as effective as no-take areas. Additionally, partial protection is no more effective than areas with little to no regulation.

\section{Ways forward}

The return to the local scale of management represents a type of contemporary adaptation to traditional management practices. Each community will have to develop management strategies that are compatible with their unique situation. For a host of political, ethical and historical issues, it is not possible to directly implement traditional practices in the contemporary context. ${ }^{37}$ Instead, reviving traditional practices most often represents a case of adaptation of traditional with contemporary practices rather than direct transference. Environment, history and resources dictate what type of management regime is most

35 Edith Kanaka'ole Foundation, 1995. Draft Ke Kalai Maoli Ola No Kanaloa, Kaho‘olawe Cultural Use Plan. Kaho'olawe Island Reserve Commission.

36 Poepoe et al., 2007.

37 Shackeroff, J.M. \& Campbell, L.M., 2007. 
suited for each community. In areas where community ties are weak and multiple conflicting uses occur, more contemporary forms of management must be implemented.

In the United States, the landscape of federal ocean policy and management is undergoing dramatic change. A federal Ocean Policy Task Force is developing policies and standards for implementing ecosystem-based approaches and a marine spatial planning framework throughout US waters. ${ }^{38}$ The integration of TEK into marine management is unquestionably necessary, given the increasing attention to TEK both locally and nationally. It will be particularly important to ensure that TEK and traditional knowledge-holders are engaged appropriately - ethically and politically.

Despite numerous anthropogenic stressors, many of Hawai'i's coral reefs, primarily in remote areas, are still in fair to good condition compared to elsewhere around the world..$^{39}$ It is therefore urgent to develop management strategies that can alter the current trajectory of resource declines and improve the quality of these resources for future generations before a tipping point is reached. Traditional knowledge and community are critical to achieving these goals.

\footnotetext{
38 Presidential memorandum, 12 June 2009. 'National policy for the oceans, our coasts, and the great lakes'. www.whitehouse.gov/sites/default/files/page/files/2009ocean_mem_rel.pdf. Accessed 17 August 2015.

39 Friedlander, A., Aeby, G., Brainard, R., Brown, E., Chaston, K., Clark, A., McGowan, P., Montgomery, T., Walsh, W., Williams, I. \& Wiltse, W., 2008. 'The state of coral reef ecosystems of the main Hawai'ian islands'. In J.E. Waddell \& A.M. Clarke (eds), The State of Coral Reef Ecosystems of the United States and Pacific Freely Associated States: 2008. NOAA Technical Memorandum NOS NCCOS 73. Silver Spring, MD: NOAA/NCCOS Center for Coastal Monitoring and Assessment's Biogeography Team, pp. 158-99.
} 
This text is taken from The Rahui: Legal pluralism in Polynesian traditional management of resources and territories, edited by Tamatoa Bambridge, published 2016 by ANU Press, The Australian National University, Canberra, Australia. 